\title{
The incretin axis offers a novel therapeutic target to preserve myocardial energy metabolism in cardiorenal syndrome
}

\author{
Marie A Schroeder ${ }^{2 *}$, Chuck Cunningham², Albert Chen², Kim A Connelly ${ }^{1}$ \\ From 19th Annual SCMR Scientific Sessions \\ Los Angeles, CA, USA. 27-30 January 2016
}

\section{Background}

Clinical and epidemiological data have identified a cardiorenal syndrome (CRS), in which heart and/or kidney failure accelerates dysfunction in the other organ. New therapeutics are needed to target the mechanisms that cause CRS and treat the whole patient. The aims of this study were to 1) assess in vivo cardiorenal metabolism using hyperpolarized ${ }^{13} \mathrm{C}$ MR spectroscopy (MRS) in experimental CRS, and 2) to test the hypothesis that normalizing aberrant metabolic reprogramming could provide CRS therapy.

\section{Methods}

The diabetic Goto-Kakizaki [GK] rat, aged to 40 weeks, were used as a model of secondary CRS and compared with age matched Wistar controls. Animals underwent echocardiography at 8 weeks of age, and subsequently every 4 weeks. A cohort of paired animals $(n=5)$ underwent invasive cardiac catheterization for pressure-volume (PV) loop analysis. In a second cohort of animal pairs $(n=$ 4), hyperpolarized $\left[1-{ }^{13} \mathrm{C}\right]$ pyruvate was infused intravenously and ${ }^{13} \mathrm{C}$ MR spectroscopic data were acquired from hearts and kidneys. An interleaved pulse-acquire pulse sequence was used $(1.2 \mathrm{~cm}$ axial slice through alternately heart or kidneys, $20^{\circ}$ tip angle, $\mathrm{TR}=1 \mathrm{~s}$ ). Daily treatment with glucagon-like peptide-1 (GLP-1) receptor agonist liraglutide $(0.2 \mathrm{mg} / \mathrm{kg})$ was given to a third cohort GK rats for 10 weeks $(n=4)$ prior to ${ }^{13} \mathrm{C}$ MRS assessment of metabolism. Cardiac and renal tissue was collected for histopathological and molecular analysis.

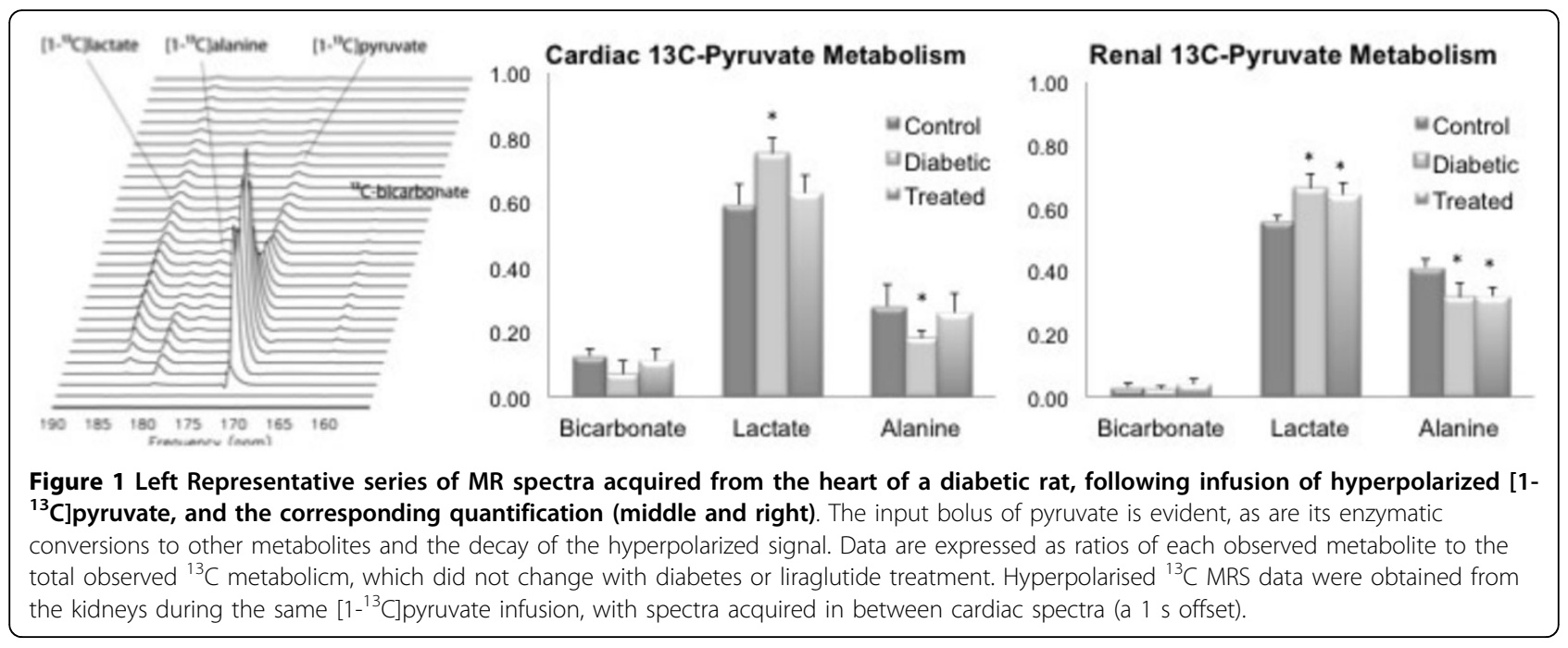

${ }^{2}$ Sunnybrook Health Sciences Centre, Toronto, ON, Canada

Full list of author information is available at the end of the article

(c) 2016 Schroeder et al. This is an Open Access article distributed under the terms of the Creative Commons Attribution License (http://creativecommons.org/licenses/by/4.0), which permits unrestricted use, distribution, and reproduction in any medium, provided the original work is properly cited. The Creative Commons Public Domain Dedication waiver (http://creativecommons.org/ publicdomain/zero/1.0/) applies to the data made available in this article, unless otherwise stated. 


\section{Results}

Glycated hemoglobin (HbA1c) confirmed that GK rats were diabetic at 20 weeks. Forty-week-old untreated GK rats developed proteinuria, LV hypertrophy, and pulmonary congestion. PV-loops demonstrated preserved systolic, yet impaired diastolic function. Histology demonstrated myocyte and glomerular hypertrophy, interstitial fibrosis and glomerulosclerosis. Hyperpolarised ${ }^{13} \mathrm{C}$ MRS data indicated that cardiorenal carbohydrate metabolism was reprogrammed to promote lactate production over oxidation (Figure 1). In the kidney, ${ }^{13} \mathrm{C}$-lactate was increased at the expense of ${ }^{13} \mathrm{C}$-alanine. Metabolic reprogramming was likely mediated by inflammation (in both organs, macrophage infiltration and toll like receptor 4 protein expression were increased) or maladaptive systemic gluconeogenesis (renal Pck1 and G6pc mRNA were increased). Liraglutide treatment reduced HbA1c levels in GK rats by $13 \%$. The drug normalized carbohydrate utilization to abrogate ${ }^{13} \mathrm{C}$-lactate production in the heart (Figure 1). In the kidney, no effect of liraglutide treatment was observed.

\section{Conclusions}

Hyperpolarized ${ }^{13} \mathrm{C}$ MRS identified that in diabetesinduced CRS, whole-body carbohydrate utilization was impaired and represented a novel target for therapy. We conclude that 1) non-invasive metabolic assessment using hyperpolarized ${ }^{13} \mathrm{C}$ MRS offers an important tool to investigate the pathology of multi-organ diseases, and to identify and evaluate new therapeutic approaches, and 2) that liraglutide therapy may have a role in treating diabetesinduced CRS by preserving myocardial function.

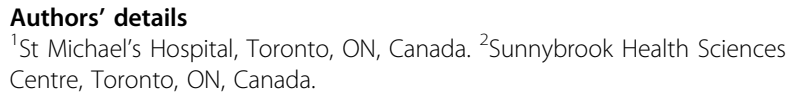

Published: 27 January 2016

\section{doi:10.1186/1532-429X-18-S1-015}

Cite this article as: Schroeder et al:: The incretin axis offers a novel therapeutic target to preserve myocardial energy metabolism in cardiorenal syndrome. Journal of Cardiovascular Magnetic Resonance 2016 18(Suppl 1):015.

\section{Submit your next manuscript to BioMed Central} and take full advantage of:

- Convenient online submission

- Thorough peer review

- No space constraints or color figure charges

- Immediate publication on acceptance

- Inclusion in PubMed, CAS, Scopus and Google Scholar

- Research which is freely available for redistribution

Submit your manuscript at www.biomedcentral.com/submit 